\title{
An Action Research Endeavor with International Student Teaching Assistants for Their Development as Teaching Professionals
}

\author{
Takaaki Hiratsuka \\ Department of Global Studies, Ryukoku University, Kyoto, Japan
}

\begin{abstract}
Research on the experiences of international student teaching assistants (TAs) in the context of Japan is scarce even though for the majority of TAs the position provides them with their first experience of being an educator at the university level. In this research, I used an action research methodology to better understand and improve the quality of classroom life with three international student TAs. Data were gathered, using interviews, picture drawing, and classroom field notes. Overall, there was an agreement among the participants that the action research endeavor enabled them to feel empowered as teacher professionals in that they reported increases in both their collaboration with me (the course instructor) and the frequency and quality of their engagements with their students. They also noted that the feedback they received from and offered to me became more insightful and wide-ranging. I will conclude this article with my recommendations for future research on TAs.
\end{abstract}

Index Terms-international student teaching assistants (TAs), professional development, action research, picture drawing

\section{INTRODUCTION}

In recent years, the number of international teaching assistants (TAs) teaching undergraduate courses, including second language courses, has increased dramatically. This increase is born partly from efforts to promote internationalization on campus (Robson, Almeida, \& Schartner, 2018). Playing the role of TAs constitutes an essential part of many international graduate students' day-to-day lives and is considered to be "an integral activity for their academic professionalization" (Zheng, 2017, p. 30). Despite this, there are few empirical studies about them; in particular, research on the experiences of international TAs in the context of Japan is scarce, and longitudinal reports on their TA experiences even scarcer. For the majority of TAs, however, the position is an introduction into being an educator at the university level. Crucially, Ueno and Maruyama (2010) claimed that one of the most salient characteristics of the TA system in Japan is that there is scant opportunity for TAs to develop their teaching abilities. Against this backdrop, it is important to conduct more research on this issue and critically analyze current practices, role assignments, and expectations which impact on the professional development of TAs as pre-service/novice teachers.

It was out of necessity that my TAs and I made the decision to launch this action research within undergraduate-level English language courses. During our initial meetings before the semester, the TAs could not help but openly express their frustration at their previous TA experiences and/or concerns about being my TA. Since I was new to the university and had never had the luxury to hire TAs at my previous institutions, I myself did not know much about how to use TAs or what to do about their apprehensions. After our initial distress passed, we felt an overwhelming desire to make our experiences in the courses better for our students and for ourselves. Coupled with this desire was my unsettling awareness that researchers and institutions have not heretofore closely inspected the experiences of TAs in this context. In mutual pursuit of an enriched experience, we agreed that we would carry out an action research project in which we, as both teachers and researchers, observe each other, take notes in class, and engage in considerable discussion (Borg, 2013; Burns, 2005). This study is therefore of value mainly for two reasons. First, it provides additional information about the experiences of TAs, which has been conspicuously under-explored especially in the field of English language education in Japan. Second, it exemplifies how TAs, as legitimate novice teachers, are deserving of professional development opportunities within their particular contexts.

\section{LITERATURE REVIEW}

There has been an intensified move towards professionalizing the practice of TAs at the university level in the last few decades, particularly in the United States and the United Kingdom (e.g., Park, 2004; Winter, Turner, Gedye, Nash, \& Grant, 2014). Concurrently, researchers have explored the topic empirically and started to unveil TAs' instructional perceptions and practices (Addy \& Blanchard, 2010; Deacon, Hajek, \& Schulz, 2017), concerns and challenges (Cho, Kim, Svinicki, \& Decker, 2011; Muzaka, 2009), as well as roles and identities (Fairbrother, 2012; Winstone \& Moore, 2016). Improvement of students' attitudes towards international student TAs was the focal point of Manohar and 
Appiah's (2015) study. While Manohar and Appiah acknowledged that undergraduate students across the U.S. universities often evaluated international student TAs negatively, they demonstrated one way in which to increase the students' willingness to support international student TAs through a perspective taking intervention. In the field of English language education in particular, Lee's (2016) mixed methods study conducted in the United States examined the relationships between lecturer's oral corrective feedback and changes in 60 international student TAs' language anxiety levels. The results highlighted that the use of corrective feedback generated both positive and negative emotional states in the international student TAs. In a similar vein, Zheng (2017) investigated the experiences of two English department international student TAs at a public university in the United States by employing an ethnographic multiple case study approach. The study revealed that each international student TA had a distinctive linguistic identity and enacted each respective translingual identity to varying degrees, due to their different language learning histories.

In the context of Japan, there exist relatively few examples of empirical research about TAs, let alone international student TAs. One such study concerning TAs in general, however, is Kaibara's (2011) study in which he found that Japanese national universities utilize TAs in a limiting and monotonous way, by and large treating them as mere administrative and clerical staff. Shin, Hirai, and Horie (2016), on the other hand, proposed a developmental model of TAs who were involved with undergraduate courses at a university in Japan. The interview data from 10 Japanese TAs suggested that TAs' intentions and commitment as well as such stakeholders as their mentors and peers are key to the optimal developmental processes and growth of TAs. Shin, Hirai, and Horie's (2016) is thus one of the views that illuminated the issue of TA professional development in Japan. More recently, Fujishiro and Hozaki (2018) interrogated the experiences of three Japanese TAs in a course called Media Production Studies, via the use of the TAs' field notes. The main results of the study were that each TA paid attention to different cohorts of students when teaching (e.g., classroom as a whole vs particular students) and engaged in dissimilar types of reflective activities (e.g., forwardlooking vs backward-looking), depending on their prior TA experiences and the duration of the experiences. Haswell's (2017) study is most pertinent to my current study. He investigated how a TA program at a Japanese university affected the campus lives of international students who were employed as TAs. Among his findings, what was particularly notable was that the participants regarded their TA role as being vague. It was also reported that even though the TAs expected to support the teacher both inside and outside the classroom, they were more likely to be confined to a nonteaching, clerical work. Following on from Haswell (2017), the current study also attempts to look into the lives of international TAs at a Japanese university. However, the current study significantly differs in that (a) the participating international student TAs in this study are graduate students as opposed to undergraduate students, (b) the research context of this study is one of the largest national universities as opposed to one of the most highly-internationalized private universities, and (c) this study has incorporated an action research component over time with its focus on teacher education as opposed to a descriptive study that documented TA perspectives at a certain fixed time. Thus, the research question formulated for this study was: What effects does an action research endeavor have on the experiences of international student TAs at a Japanese national university?

In order to be guided in answering the above question more effectively, one assumption I made at the outset of this study was that a course instructor and a TA at the university level are essentially engaged in one type of team teaching. Therefore, the literature and discussion surrounding team teaching in English language education at Japanese schools appeared to be quite relevant and useful as well. For more than three decades, foreign assistant language teachers (ALTs) have been paired up with local Japanese teachers of English (JTEs) for the advancement of foreign language education in Japan (CLAIR, 2020). Several empirical studies on the topic revealed that the team teachers were unclear and ambivalent about the roles of their own and their partner's and held unique, sometimes even diametric, perceptions about them (e.g., Hiratsuka, 2015; Mahoney, 2004). It was also found that ALTs felt underused and experienced frustration when they were treated as merely a human tape recorder (McConnell, 2000) as well as when they had no meaningful connection with their students (Hiratsuka, 2015). Power imbalance between the team teachers was the focal issue in Miyazato's (2009) study (see also Hiratsuka, 2017a). Under these circumstances, Tajino, Stewart, and Dalsky (2015) attached great significance to collaboration among team teachers and students and introduced the concept of team learning where all the stakeholders "share a core value that places priority on collaboration in ways that enhance 'quality of life' in the classroom" (Tajino \& Smith, 2015, p. 24, emphasis in the original). Likewise, Hiratsuka (2017b) documented the learning trajectories of team teachers through pair discussions involving video-stimulated recall and demonstrated the value of dialogic and cooperative practices between them that led to fruitful professional development. These studies concerning team teaching between JTEs and ALTs hence became the catalyst for answering the research question and functioned as main reference sources during the phases of data interpretation and discussion of this research.

\section{Methodology}

\section{A. The Participants}

The action research project was carried out during the fall semester of 2017. The contexts were three undergraduatelevel English language courses (English A, B, and C) that I taught once a week for 90 minutes over the course of 15 weeks at one of the largest national universities in northern Japan. The content and goals of the three courses were 
primarily the same: to cultivate the four skills of English (speaking, writing, reading, and listening) for academic purposes. Before the semester, the university helped me to find and hire TAs for each course. I interviewed several candidates from the list provided by the university that specified graduate students who expressed their wish to be hired as TAs. After the interviews, I recruited three TAs (Peter, Maria, and Chloe) on the basis of their personal and professional experiences in teaching, their social activities at the university, and their high levels of English proficiency. I assigned Peter as my TA for English A, Maria for English B, and Chloe for English C (see TABLE I ). All names of courses and participants are pseudonyms.

TABLE 1

PARTICIPANTS IN THE STUDY

\begin{tabular}{|c|c|c|c|}
\hline Participant name & Peter & Maria & Chloe \\
\hline Age & 24 & 29 & 25 \\
\hline Gender & Male & Female & Female \\
\hline Nationality & Vietnamese & Vietnamese & Chinese \\
\hline Pursuing degree & $\begin{array}{c}\text { Master's } \\
\text { (Economics) }\end{array}$ & $\begin{array}{c}\text { Master's } \\
\text { (Economics) }\end{array}$ & $\begin{array}{c}\text { Master's } \\
\text { (Economics) }\end{array}$ \\
\hline $\begin{array}{l}\text { Total TA work } \\
\text { hours for the } \\
\text { course }\end{array}$ & $\begin{array}{c}20 \text { hours } \\
\text { (15 hours in the classroom; } \\
5 \text { hours marking) }\end{array}$ & $\begin{array}{c}20 \text { hours } \\
(15 \text { hours in the } \\
\text { classroom; } 5 \text { hours } \\
\text { marking) }\end{array}$ & $\begin{array}{c}20 \text { hours } \\
\text { (15 hours in the classroom; } \\
5 \text { hours marking) }\end{array}$ \\
\hline $\begin{array}{c}\text { Number of } \\
\text { semesters as a TA } \\
\text { previously and type } \\
\text { of courses }\end{array}$ & 0 & $\begin{array}{c}1 \\
\text { (English language } \\
\text { teaching; Statistics) }\end{array}$ & $\begin{array}{c}2 \\
\text { (Chinese language } \\
\text { teaching) }\end{array}$ \\
\hline $\begin{array}{c}\text { Number of } \\
\text { semesters at the } \\
\text { university }\end{array}$ & 3 & 3 & 4 \\
\hline $\begin{array}{c}\text { Foreign language } \\
\text { proficiency }\end{array}$ & $\begin{array}{l}\text { Advanced } \\
\text { (English) } \\
\text { Beginner } \\
\text { (Japanese) } \\
\end{array}$ & $\begin{array}{l}\text { Advanced } \\
\text { (English) } \\
\text { Beginner } \\
\text { (Japanese) } \\
\end{array}$ & $\begin{array}{l}\text { Advanced (English) } \\
\text { Advanced (Japanese) }\end{array}$ \\
\hline Course in charge & English A & English B & English C \\
\hline $\begin{array}{l}\text { Major of students } \\
\text { in the course }\end{array}$ & Engineering & Education \& Literature & Science \\
\hline $\begin{array}{c}\text { Number of } \\
\text { students in the } \\
\text { course } \\
\end{array}$ & 39 & 37 & 28 \\
\hline
\end{tabular}

\section{B. Data Collection and Data Analysis}

Data were collected through interviews, picture drawing, and classroom field notes. I describe below the data collection and data analysis methods employed in this study.

\section{Interviews}

Interviews as a qualitative data collection method can provide participants with an impetus for scrutinizing their perceptions and narrating their experiences. As such, I made a decision to conduct interviews with each TA before and after the semester. Since this study was as much theirs as mine, I purposefully chose to have an unstructured interview. Prior to beginning, I informed the TAs that the interview was more of a free-flowing conversation between us on a general topic (i.e., our overall teaching experience) rather than a data collection interview with a set of pre-determined agendas and questions on a particular issue. The interviews lasted about 90 minutes each in English in my office at the university. All interviews were recorded and analyzed through content analysis, an inductive strategy that determines codes and categories by identifying significant saliencies and commonalities with respect to participants' TA experiences (Bogdan \& Biklen, 2007).

\section{Picture drawing}

Within the social sciences, visual representations, such as researcher-initiated picture drawing, have been used as a data collection method (Pauwels, 2010). Kelly (2018) adopted this data collection method and asked 12 pre-service teachers in a community college to draw pictures of teachers teaching English at both the beginning and end of their course. In a very similar manner to her study, immediately before the interviews were carried out at the beginning and end of the semester, I asked the participating TAs to draw pictures of what it means to be a TA in English language courses at the university. They did not have access to the first picture when they drew the second one. During the first interview, we discussed the first picture they drew and negotiated the roles we would play in the course, possible 
pedagogies we could implement, and instructional content we would deal with. During the second interview, we looked at both the pictures drawn and exchanged thoughts about the convergences and divergences between them. All the drawing data were analyzed through visual content analysis, a systematic observational method that allows researchers to classify data into idiosyncratic categories (Bell, 2004; Kelly, 2018).

\section{Classroom field notes}

Unless we examine what teachers and students say and do in the classroom in which they actually work and learn, we cannot gain an authentic and thorough insight into their teaching and learning (Fanselow, 2018). The TAs and I therefore decided to take classroom field notes while we were either free from classroom duties during the lesson or immediately after the end of it. We wrote brief descriptions of the physical environment and the students as well as jotted down details of utterances made in the lesson or of any kind of event or incident we noticed.

\section{FINDINGS}

There was an overall agreement among the TA participants that the action research endeavor assisted them to feel empowered as teacher professionals in that, in comparison to their previous experiences or expectations, (a) there was more fruitful collaboration with the course instructor (me), (b) there were more engagements with their students, and (c) the feedback they received from me and provided to me was more insightful and wide-ranging.

\section{A. Collaboration with the Teacher}

It was immediately apparent, by comparing the first and second drawings, especially those of Peter and Maria, that in the TAs' minds the level of collaboration and coordination between the TAs and the instructor in the course was high. Although Peter drew in the first picture (see Fig. 1) that the course instructor and TA stand far from each other at the front of the classroom and do not seem to communicate, in his second picture both teachers stand in close proximity and appear to engage in a dialogue. Maria's first picture (see Fig. 2) featured the course instructor sitting at the desk and the TA using a copy machine in the office. They seem to look at opposite directions and work on their respective work on their own. Her first picture also showed that the course instructor is teaching in front of the blackboard in the classroom alone while the TA is nowhere to be seen. In contrast, Maria drew in her second picture the course instructor and the TA sitting face-to-face and appearing to have a conversation in an office. She also drew in the second picture that the course instructor stands behind the podium and that the TA sits amongst the students while facing toward one of the students. There was thus a remarkable difference between the first and second pictures with respect to the level of collaboration between them.

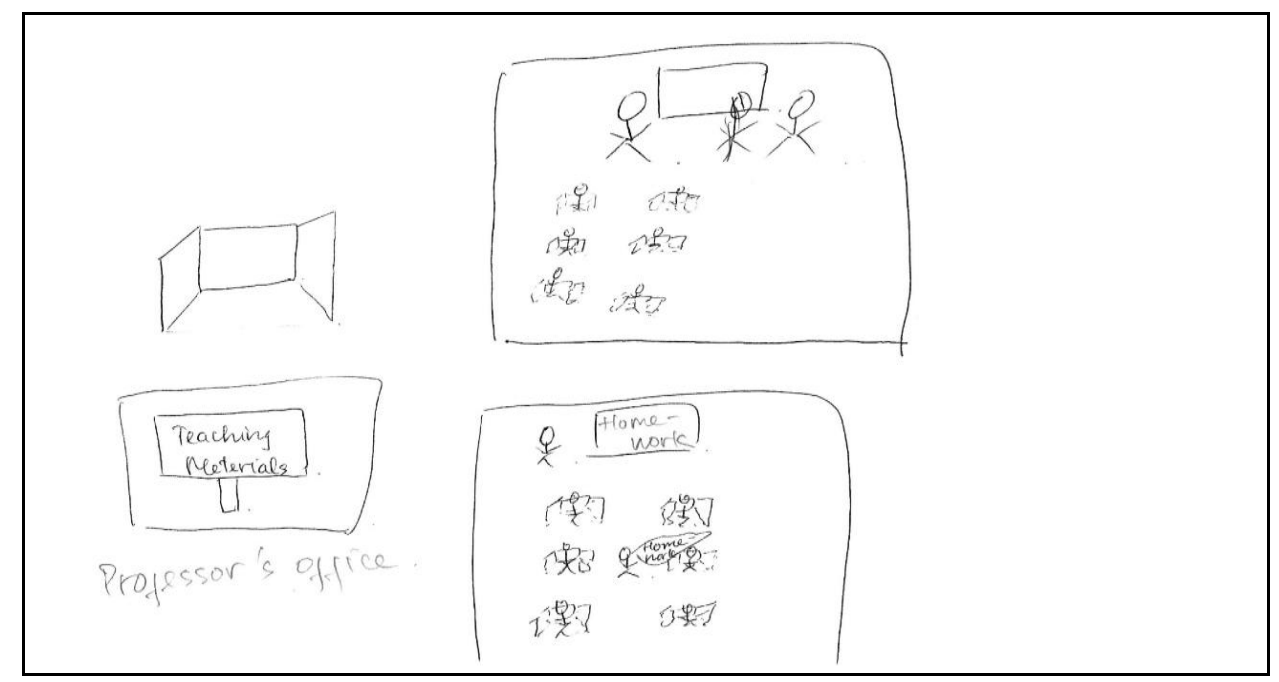




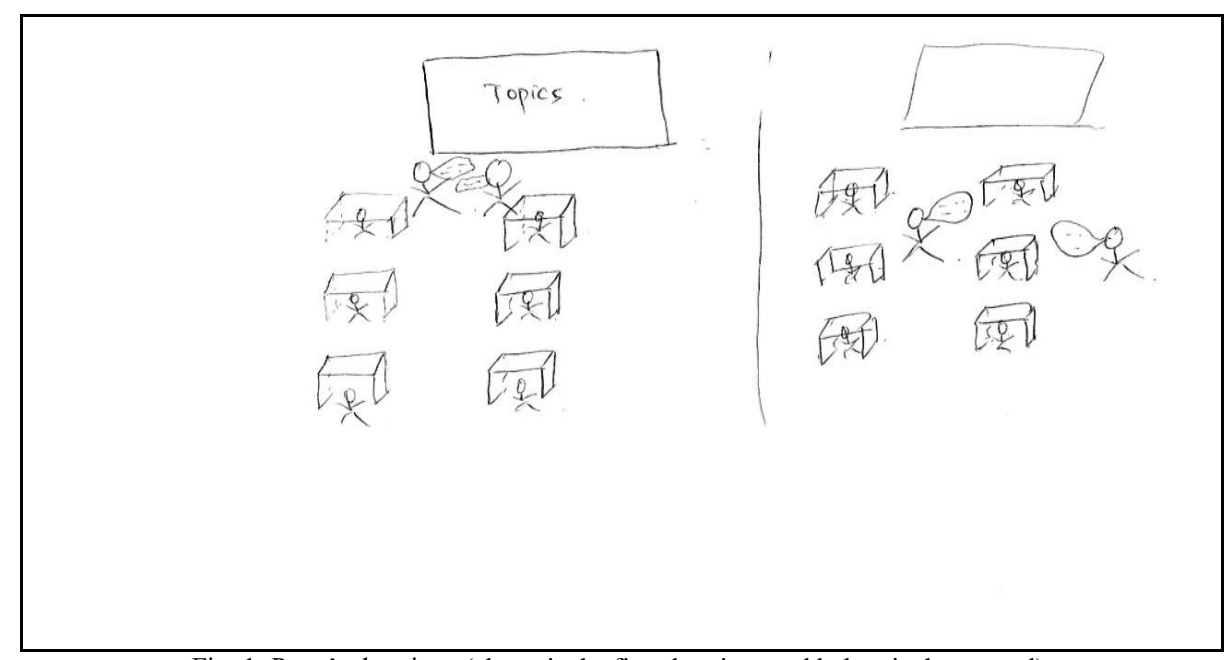

Fig. 1: Peter's drawings (above is the first drawing, and below is the second).
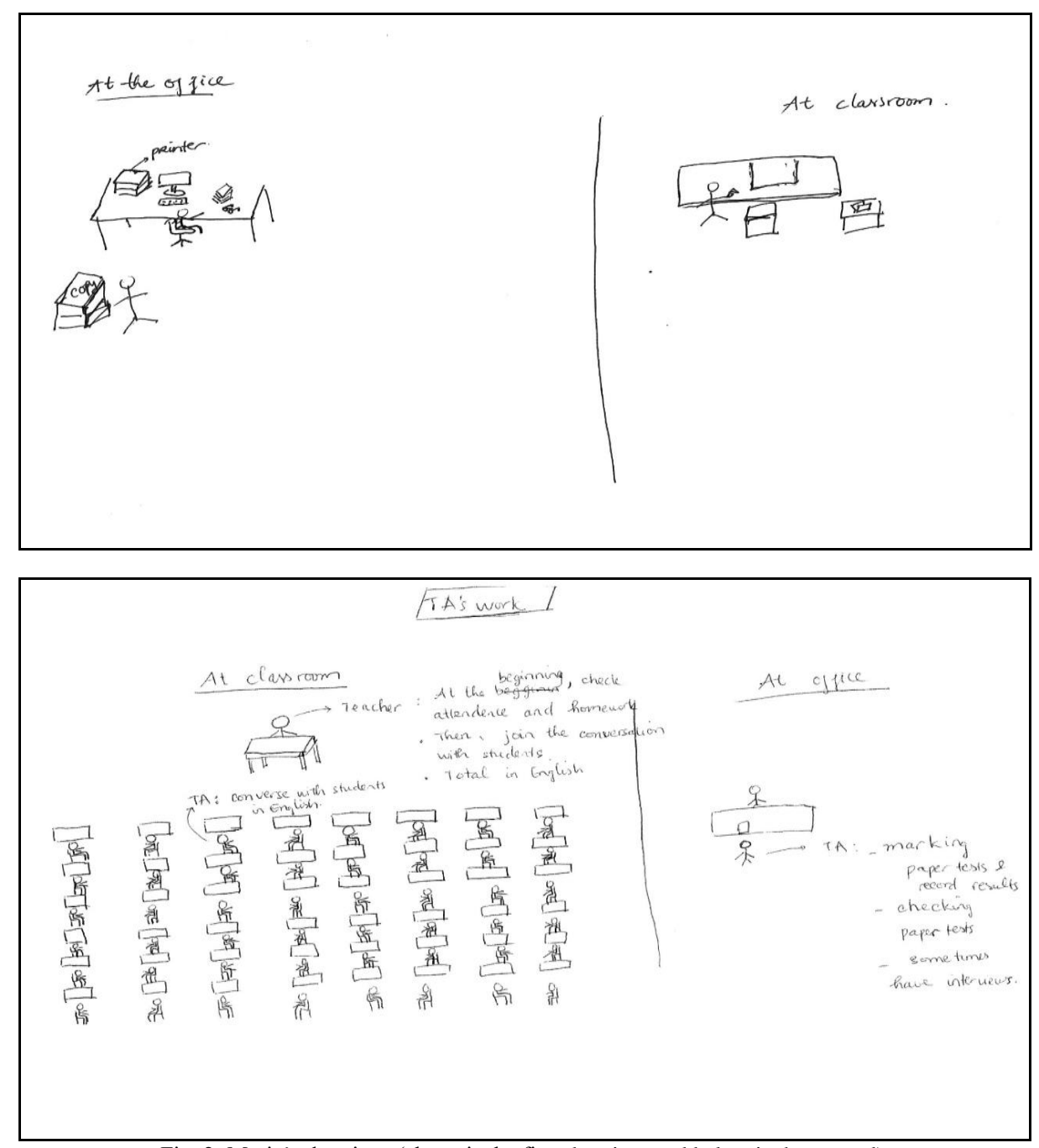

Fig. 2: Maria's drawings (above is the first drawing, and below is the second).

This theme of collaboration was also noticeable in their interview data. In his first interview, Peter was eager to find out what he was supposed to do as a TA and asked me questions such as: "Do you want me to prepare reading materials or copy something and set up the computer before the class?" He identified the role of TA as being the helper for the course instructor, and imagined the job entailed clerical and technical work mainly outside of the classroom, independent from the instructor. His comment reflects this: "For me, being a TA is first and foremost supporting the instructor.... TAs copy materials and check homework of the students. Basically, all of this gets done between lessons without much guidance. That's what I heard TAs do" (Interview 1, Peter). At that point, he did not seem to associate the TA job as being involved in teamwork with the course instructor. In his view, therefore, there is a marked division of 
labor between the TA and course instructor, and their communication is kept to a minimum. In his second interview, however, he appeared to have changed his perceptions of TA work from being isolated individual duties towards more opportunities for collaborative tasks with the course instructor. He attributed this at least partly to our action research project: "This action research project and the interview opportunities have allowed me to talk to you a lot and freely discuss what we do and what we can do to make the course better". He continued, emphasizing the importance of collaboration: "I like our current collaborative style. Although I basically had no teaching experience, I felt like I could make use of my personal experience and knowledge more this way and contribute to the students as a team member". He then quickly added: "Doing paperwork alone would have been terribly boring!"

Maria also seemed to have radically modified her earlier perceptions of the TA role. In the second interview, she commented:

Previously, my image was that I, TA, should prepare materials and do paperwork in the professor's office and I do not need to come to the classroom. Now it is totally different, and I had to get involved with classroom activities and exchange ideas with you outside the classroom. And I loved that. (Interview 2, Maria)

Maria admitted that she could enjoy the close involvement she had with me and class activities in the course more than she initially imagined. In Chloe's interviews, as well, the change in perception of a TA's role became evident. During her first interview, though somewhat unsure, she presented her ideas about the role of TA being secretarial: "TA sits on the chair, make copies, and check tests. I assume that TA has to prepare the blackboard and power point slides for the teacher? I don't know". During her second interview, on the contrary, she said that to her surprise she played a more active role in the classroom in a cooperative manner with me:

We have done a lot of joint conversations as models in front of the students together. I did not feel qualified, but you let me be your conversational partner, and we spoke a lot. That was not anything I expected or experienced before. (Interview 2, Chloe)

As seen in the examples above, after the action research experience, the TAs came to believe that TAs and course instructors could be more collaborative and work together for shared goals. They also asserted that their job should not be just limited to clerical work but should be more pedagogically meaningful. Although the experience they had had as TAs or the anecdotes they had heard from others prior to the project had led them to deem that the TA presence in the classroom was uncommon and their involvement with the teacher constrained, the TA participants in this study reported that they had more positive experiences and that the action research activities such as collaborative reflection and discussions with me facilitated that.

\section{B. Engagement with Students}

In addition to the increase in collaboration with the course instructor, another intriguing contrast shown in the illustrations by Maria (see Fig. 2) is the involvement level the TA had with students. Again, although the TA was nowhere to be seen in her first picture, Maria drew a TA sitting amongst the students in the classroom. The description of her second picture reads: "TA: converse with students in English". It seems that Maria came to understand that one vital job of TA is to participate actively in conversations with students in the classroom, as opposed to being only in charge of clerical work and not attending the lessons. Similarly, what seems most striking in Fig. 3 drawn by Chloe is the change in the level of engagement the teachers have with students. That is, Chloe in the first picture sketched out a TA responsible for handling computer equipment, sitting at the front row alone, and working on test marking by herself. In all the cases, the TA works at one place, distancing himself/herself from the course instructor or any of the students. By comparison, the TA portrayed in her second picture is mobile, sometimes walking near the students and at other times positioning himself/herself alongside the students as a member of the group at a table. 

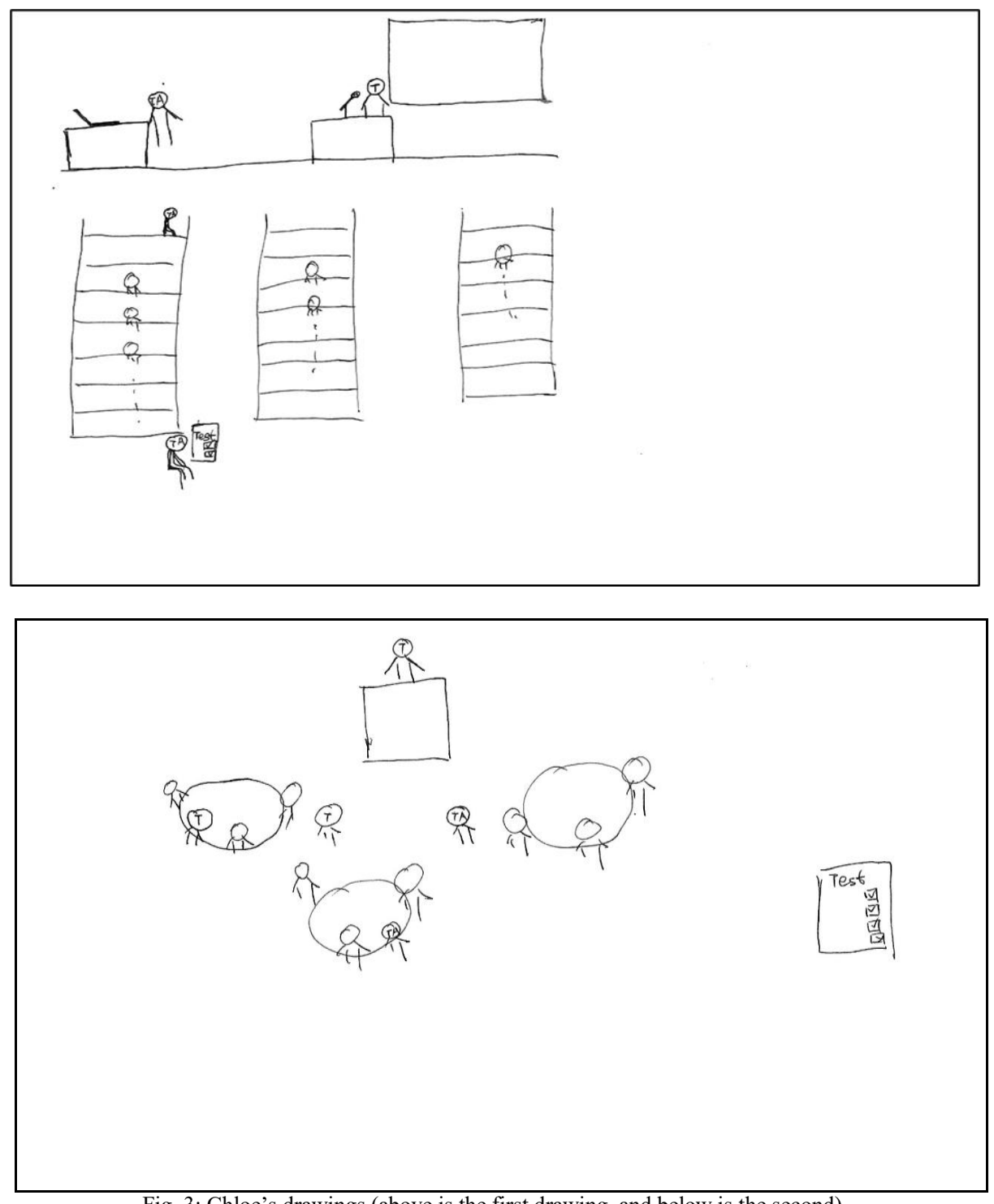

Fig. 3: Chloe's drawings (above is the first drawing, and below is the second).

Interview data also pointed to the advancements of the TAs' engagement with students. Looking at both pictures and responding to my prompt: "What are the similarities and differences between the pictures you drew before and now?" (see Fig. 1), Peter remarked: "I think there are some similarities in that the job of TA is to support the teacher and the class. But the second drawing suggests that TA is communicating and interacting with students" (Interview 2, Peter). Peter then spoke about the personalities of Japanese people, speculated on the students' experiences in the course, and conveyed his impression of the course with excitement: "Not many Japanese students share their personal opinions or experiences. But in those classes, they did.... I hope the students enjoyed speaking about personal topics to me and to other classmates. I certainly did!" (Interview 2, Peter).

Several examples also surfaced in Maria's interview which illustrated that she engaged more with the students as the course progressed. She reported what she did in the course and explained her preference:

In your classroom, I conversed with students in English and I became more active by interacting with them. Personally, I really like being involved with the students and interacting with them because I love talking to many people and exchanging ideas. I also love the students to practice speaking English. (Interview 2, Maria)

She was well aware of the transformations her students underwent in terms of their attitudes toward the use of English and their communication abilities in it over the semester. She seemed to be excited to witness the development and provided possible reasons for why it took place: "Toward the end of the course they talked a lot more and gave me substantial information about themselves. One possible reason for this was they got used to me, and the other was their English-speaking skills improved" (Interview 2, Maria).

Chloe also perceived the shift in the level of engagement she had with students. She mentioned in her second interview that she, as a TA, had more connection with students in the course we taught together than previous courses she was a TA for: "Most of the work I did when I was a TA for Chinese language classes was paperwork. But, in this 
course I spoke to students and moved around freely in the classroom" (Interview 2, Chloe). Afterwards, she further articulated her enthusiasm about the pedagogical style we employed whilst offering her reasons:

I liked having direct contact with the students. By talking to them, I could detect which part they had difficulty with and how they were learning English. If I just sat in front of the class, I would not have known whether they were understanding the lesson or not. With individual contact, I could give suggestions by listening to them and looking at their faces. (Interview 2, Chloe)

The drawings and interview responses above exhibit that the TA participants were likely to have felt that the courses offered a platform for them to interact directly with their students in the classroom more than they had imagined or experienced previously. In particular, Maria and Chloe who had had TA experience at the university before were keenly cognizant that the level of engagement they could gain through close communication with the students in the courses was quite high, something they did not expect as a TA because they considered its principal job to be clerical work occurring outside the classroom.

\section{Feedback from and for the Instructor}

The TA participants were unanimous that the action research activities, including two official interviews and a number of spontaneous discussions throughout the semester, yielded opportunities for them to receive and provide insightful feedback on wide-ranging topics. For example, Peter remembered several instances during the course where he was encouraged by me to introduce his culture and language learning experience to the students:

To be honest, I am not an extroverted person. I am talkative only when my close friends are around. But I could sort of change that shy personality because you let me freely talk about myself, Vietnam, and my English learning experience. At one point, you let me be in charge of the half of the students and after the class we shared our experiences and gave feedback to each other. I think it was good for those students. (Interview 2, Peter)

He also referred to a specific pedagogical strategy we could have used for the course: "It might be better to increase the frequency of group work a little more, rather than always using pair activities" (Interview 2, Peter). His responses might be a signal that he began to enhance his confidence and demonstrated his ability as a teaching professional. Drawing upon her previous TA experience, Maria expressed her opinion on the TA arrangement, indicated what is necessary for its success, and affirmed that there had been open communication between her and me during the semester:

The TA program itself is not bad, but to make it better, the teacher and TA need to get along with each other and be on the same page. It is all about how compatible they are. As a TA, I did not have any idea or control before, but this time round I could make suggestions about the tests, class activities, and so on. (Interview 2, Maria)

Looking towards the future, Maria envisaged that the TA experience, especially those gained inside the classroom, would be useful for her professional career: "The tweaks and suggestions you gave me on the spot in the classroom helped me to know how to make the lesson lively and encourage students to have confidence" (Interview 2, Maria). Her statements indicated that, contrary to some anecdotes as well as some of the previous academic discussion, TA experiences in the Japanese university context can aptly serve as a beneficial pre-service teacher education opportunity for international students.

Although Chloe acknowledged that she could receive and provide feedback in the course with me, she was doubtful about the possibility that this mutual feedback provision would take place with other professors: "Professors have been using the same textbook and keeping the same teaching style for many years. I don't think they are willing to change their situations so much" (Interview 2, Chloe). Chloe hypothesized that it is difficult for veteran professors who have established their own teaching styles to modify their classes after many years. She held a view that those veteran professors who do not put themselves on the same footing as TAs might limit their meaningful professional development for both themselves and their TAs, with this power imbalance being particularly detrimental to the TAs. This is a serious concern and merits further attention, given that all the TA participants in this study told me that one of the main reasons to sign up for the TA job was to learn how to teach at the university level and develop as educators so as to enhance their future employment prospects.

The comments above, together with data from the classroom field notes (e.g., "Teacher told me that asking the same questions he asked to the whole class during my conversation with each student would promote student learning" (Classroom field note, Peter)), suggest that the TAs appreciated and found value in the chance to both provide and receive feedback on our teaching. The feedback moments they shared might have contributed to addressing the TAs' professional needs in a practical sense while offering them a fruitful avenue for constructing their emerging professional identities as legitimate educators.

\section{DISCUSSION}

Peter had no prior TA experience but had formed an image of the TA after listening to his friends' stories as someone who carries out clerical work away from the classroom. Maria had several negative experiences of being a TA before 
primarily because her previous instructors did not regard her as a fully-fledged educator and treated her virtually as a personal secretary. Chloe felt underexploited as a TA previously despite her great desire to learn tips about teaching a second language. In an attempt to improve the TAs' experiences, an action research project was planned and executed over the course of a semester. Findings of this study suggested that, on the whole, the participants were positive about their experiences. In particular, compared to their previous experiences or expectations, they appeared to have (a) collaborated with the course instructor more, (b) had more personal engagement with students, and (c) exchanged feedback with the instructor more.

Previous research in the United States inferred that international student TAs in language classrooms have been marginalized due to their linguistic-related anxieties and their self-perceived demoralizing identities (Lee, 2016; Zheng, 2017). In the context of Japan, also, international student TAs have been de-professionalized due to their limited educational responsibilities given by their instructors (Haswell, 2017; Kaibara, 2011). This project has been carried out to critique this entrenched practice by employing an action research intervention in English language lessons at a Japanese university. The endeavor led to improved professional development outcomes both for the course instructor and more importantly for the TAs.

One primary finding of the project suggests that there was increased collaboration between the course instructor and the TAs inside the classroom, in addition to outside (see also Hiratsuka, 2017b; Shin, Hirai, \& Horie, 2016; Tajino, Stewart, \& Dalsky, 2015). I attribute this achievement to the facts that (a) we championed and modeled the value of a joint venture within the project without pre-determining our roles in accordance with the expectations we might have had previously and that (b) we strived to maintain an open communication and negotiated our responsibilities together, as new desires, problems, and needs arose during the project, rather than rigidly following fixed arrangements. Hitherto, the lack of engagement with students in class has been felt by TAs in Japanese English language courses (e.g., Haswell, 2017; Hiratsuka, 2015; Kaibara, 2011). In this action research project, however, the TAs were not only allowed, but also strongly encouraged to interact with students in the classroom. This appeared to have enabled the TAs and students to feel comfortable about opening up to each other and spend quality classroom time collectively. In particular, the TAs might have cultivated their new identities as educators in a positive fashion and gained a sense of fulfillment by directly helping their students to learn in a tangible manner (see also Fujishiro \& Hozaki, 2018; Lee, 2016; Hiratsuka, 2015; Mahoney, 2004; McConnell, 2000; Zheng, 2017). Lastly, there have been findings of previous research (e.g., Hiratsuka, 2017a; Miyazato, 2009; Ueno \& Maruyama, 2010) and testimonies from the participants of this study that the power imbalance between the teachers and assistants has negatively affected the professional lives of TAs. In other words, TAs were constantly taken lightly by their instructors and oftentimes sidelined from educational goals and processes. After taking part in the action research project, however, the TAs expressed their gratitude for the opportunities during the project in which they and I could freely share our ideas and bounce around our honest thoughts on our lessons, respected roles, and beyond. This might be a testament to the serious and dedicated interests that the TAs and I had in pursuing the matter of mutual development through the project. It was easily conceivable that the TAs and I respected each other and accepted the other as a dependable contributor to the individual lessons and to the course more broadly (see also Hiratsuka, 2017b; Shin, Hirai, \& Horie, 2016; Tajino, Stewart, \& Dalsky, 2015).

The three main findings in this study (i.e., increase in collaboration between teachers, engagement with students, and feedback exchange) are heartening and somewhat unsurprising, considering that action research has been successful in providing teachers with an ideal vehicle for constant improvement in their teaching skills via the reflection and evaluation cycle (Borg, 2013; Burns, 2005). However, one possible limitation of this study is that because the participating TAs in this study spent tremendous time on and put effort into the project and because I was their coresearcher, as well as their course instructor (in a superior position), it might have been the case that the TAs had not been entirely honest during the project and not told me the whole story of their experiences. That is, they might have focused just on positive points in order to justify their commitment to the project and/or avoided talking about their negative experiences for fear that I might be upset or disappointed. Nevertheless, it is still interesting to note based on this study that it is rare and unlikely for TAs to be regarded as fully-fledged educators and find contentment in regards to their work. If anything, this study shed light on one way for this to be addressed and improved upon.

\section{CONCLUSION}

This study investigated the advantages of employing a collaborative action research endeavor in English language courses taught by three TAs and myself at a national university in Japan. It can be concluded that the endeavor could reach its goal at least partly in that, in contrast to their expectations or previous TA experiences, the participating TAs could promote a cohesive relationship with me, heightened a feeling of closeness with students, and encounter plenty of provision and receipt of feedback. Based on the findings, I suggest that the government and/or universities create empowering guidelines for pre-service and in-service TAs and treat them as legitimate educators, offer professional development seminars on TA for course instructors in order for them to maximize their TAs' potentials, and allocate time and funding for instructors and TAs to embrace feedback to each other, possibly by employing action research (see also Ueno \& Maruyama, 2010).

My recommendations for future studies pertain to: (a) research participants and contexts; (b) course instructor; and (c) research design. First, the participants in this study, my TAs, were chosen from my university because of the type of 
research (i.e., action research) as well as the adoption of a convenience sampling strategy. We need to continue in this effort by examining different participants and research sites so as to gain a fuller picture of TA experiences. Future TA participants should include domestic students or international students outside of Vietnam or China. It could also prove useful to conduct a similar study in varied research sites in Japan, especially at prefectural and private universities. Second, the TAs' course instructor (co-researcher) in this action research was me who is a Japanese language teacher of English. It is therefore imperative to accumulate more information and knowledge on the experiences of diverse course instructors. For example, the instructors can be native English-speaking teachers, other language teachers outside of English, or teachers from myriad disciplines such as economics, engineering, and medicine. Finally, future researchers can use various research methodologies. One study might be able to utilize an ethnographic approach by which researchers directly observe participants' behaviors and the phenomenon under study in the field so that it can more thoroughly document and elucidate the experiences of TAs on an intimate level. The ethnographic approach might in fact enable the TA participants to be more honest and vulnerable with the researcher about their perceptions and practices than an action research approach because the action research approach tends to involve the risk of conflict of interest, as in the case of this study. Another future inquiry might involve multiple case studies in numerous contexts (e.g., domestic and international; different education sectors) and compare and contrast the findings from them to eventually arrive, with enough accumulated research, at a holistic understanding of complicated TA experiences. My hope is that this paper and similar future studies within the field of English language education will help us view TAs as not just convenient clerical assistants but as developing teaching professionals who are keenly engaged in important learning with their course instructors, students, and peer TAs about what beneficial pedagogical practices are at the forefront of education for the ultimate improvement of language teaching and learning for all the people concerned.

\section{ACKNOWLEDGMENTS}

The author wishes to thank the participants who provided valuable insight and close collaboration.

\section{REFERENCES}

[1] Addy, T. \& M. Blanchard. (2010). The problem with reform from the bottom up: Instructional practices and teacher beliefs of graduate teaching assistants following a reform-minded university teacher certificate program. International Journal of Science Education 32.8, 1045-1071.

[2] Bell, P. (2004). Content analysis of visual images. In T. Van Leeuwen \& C. Jewitt (eds.), The handbook of visual analysis. London: Sage, 10-35.

[3] Bogdan, R. C. \& S. K. Biklen (2007). Qualitative research for education: An introduction to theory and methods (5th edn.). Boston, MA: Allyn \& Bacon.

[4] Borg, S. (2013). Teacher research in language teaching: A critical analysis. Cambridge: Cambridge University Press.

[5] Burns, A. (2005). Action research: An evolving paradigm? Language Teaching 38, 57-74.

[6] Cho, Y., M. Kim, M. Svinicki \& M. Decker. (2011). Exploring teaching concerns and characteristics of graduate teaching assistants. Teaching in Higher Education 16.3, 267-279.

[7] CLAIR. (2020). The Japan exchange and teaching program. http://jetprogramme.org/en/ (accessed 09/10/2020).

[8] Deacon, C., A. Hajek \& H. Schulz (2017). Graduate teaching assistants' perceptions of teaching competencies required for work in undergraduate science labs. International Journal of Science Education 39.1, 1-20.

[9] Fairbrother, H. (2012). Creating space: Maximizing the potential of the graduate teaching assistant role. Teaching in Higher Education 17.3, 353-358.

[10] Fanselow, J. (2018). Small changes in teaching: Big results in learning. Tokyo: iTDi.

[11] Fujishiro, H. \& N. Hozaki. (2018). A case study of the analysis of class activities observed by teaching assistants. Educational Practice Reports 24, 45-54.

[12] Haswell, C. G. (2017). Personal and professional development for international students as TAs in Japanese universities. APU Journal of Language Research 3, 60-71.

[13] Hiratsuka, T. (2015). Teachers' and students' perceptions of team-teaching practices in two Japanese senior high schools. Accents Asia 7.2, 46-66.

[14] Hiratsuka, T. (2017a). Capitalizing on the strengths and complementing the weaknesses of native and non-native English speaking teachers. OTB Forum 8.1,37-46.

[15] Hiratsuka, T. (2017b). Pair discussions for reflecting on action: Stimulated recall. In B. Barnard \& J. Ryan (eds.), Reflective practice: Voices from the field. New York: Routledge, 89-97.

[16] Kaibara, R. (2011). An inquiry into the office management of the TA system in Japan: The case of national universities. Nagoya Journal of Higher Education 11, 153-170.

[17] Kelly, L. B. (2018). Preservice teachers' developing conceptions of teaching English learners. TESOL Quarterly 52.1, 110-136.

[18] Lee, E. (2016). Reducing international graduate students' language anxiety through oral pronunciation corrections. System 56, 78-95.

[19] Mahoney, S. (2004). Role controversy among team teachers in the JET program. JALT Journal 26.2, $223-244$.

[20] Manohar, U. \& O. Appiah (2015). Perspective taking to improve attitudes towards international teaching assistants: The role of national identification and prior attitudes. Communication Education 65.2, 1-15.

[21] McConnell, D. L. (2000). Importing diversity: Inside Japan's JET program. Berkeley, CA: University of California Press.

[22] Miyazato, K. (2009). Power-sharing between NS and NNS teachers: Linguistically powerful AETs vs culturally powerful JTEs. JALT Journal 31.1, 35-62. 
[23] Muzaka, V. (2009). The niche of Graduate Teaching Assistants (GTAs): Perceptions and reflections. Teaching in Higher Education 14.1, 1-12.

[24] Park, C. (2004). The graduate teaching assistant (GTA): Lessons from North American experience. Teaching in Higher Education 9.3, 349-361.

[25] Pauwels, L. (2010). Visual sociology reframed: An analytical synthesis and discussion of visual methods in social and cultural research. Sociological Methods \& Research 38.4, 545-581.

[26] Robson, S., J. Almeida \& A. Schartner (2018). Internationalization at home: Time for review and development? European Journal of Higher Education 8, 19-35.

[27] Shin, K., T. Hirai \& M. Horie (2016). A qualitative analysis of growth process of student peer leaders and its facilitative factors: In-depth interviews with undergraduate teaching assistants at Ritsumeikan Asia Pacific University. Ritsumeikan Higher Educational Studies 16, 65-82.

[28] Tajino, A. \& C, Smith (2015). Beyond team teaching: An introduction to team learning in language education. In A. Tajino, T. Stewart \& D. Dalsky (eds.), Team teaching and team learning in the language classroom: Collaboration for innovation in ELT. London: Routledge, 11-27.

[29] Tajino, A., T. Stewart \& D. Dalsky (eds.). (2015). Team teaching and team learning in the language classroom: Collaboration for innovation in ELT. London: Routledge.

[30] Ueno, T. \& Y. Maruyama. (2010). Preparing future faculty program in Japan: Establishing a new system of training teaching assistants. Hiroshima Journal of School Education 16, 127-136.

[31] Winstone, N. \& D. Moore. (2016). Sometimes fish, sometimes fowl? Liminality, identity work and identity malleability in graduate teaching assistants. Innovations in Education and Teaching International 54.5, 494-502.

[32] Winter, J., R. Turner, S. Gedye, P. Nash \& V. Grant. (2014). Graduate teaching assistants: Responding to the challenges of internationalization. International Journal for Academic Development 20.1, 33-45.

[33] Zheng, X. (2017). Translingual identity as pedagogy: International teaching assistants of English in college composition classrooms. The Modern Language Journal 101.51, 29-44.

Takaaki Hiratsuka is an associate professor at Ryukoku University, Japan, where he teaches a range of applied linguistics courses to undergraduate and graduate school students. He received his $\mathrm{PhD}$ in language teaching and learning from the University of Auckland, New Zealand. His research and teaching interests lie in the areas of teacher education, teacher research, and qualitative research methods (in particular, narrative inquiry and practitioner research). He has recently contributed chapters to Barkhuizen (2019) Qualitative research topics in language teacher education, and Walsh \& Mann (2019) Routledge handbook of English language teacher education (with John F. Fanselow). 